\title{
Development of Mathematics Teaching Materials Based on the Realistic Mathematics Approach (PMR) to Improve the Mathematical Reasoning and Representation Ability of Class VII Students of SMP Muhammadiyah 47 Medan Sunggal
}

\author{
Ibnu Raash Aleslami ${ }^{1}$, Ani Minarni ${ }^{2}$, KMS. M. Amin Fauzi ${ }^{3}$ \\ ${ }^{1,2,3}$ Universitas Negeri Medan, Indonesia \\ raashibnu@gmail.com,animinarni10@gmail.com,aminunimed29@gmail.com
}

\begin{abstract}
This study aims to analyze the validity and effectiveness of teaching materials developed based on a realistic mathematical approach in improving students 'mathematical reasoning and representation abilities, to analyze the increase in students' reasoning skills and mathematical representation abilities taught using teaching materials based on realistic mathematical approaches. The data were obtained through the validation sheet of teaching materials, observation sheets, student response questionnaires, mathematical reasoning ability test instruments and mathematical representation ability tests. This study uses a 4-D development model Thiagarajan, Semmel and Semmel by developing teaching materials with a realistic mathematical approach. Based on the results of the validation, the total average value of the $R P P$ validity was 4.81 , the student books were 4.83 and the LKPD was 4.85 , the students' mathematical reasoning ability tests and the mathematical representation ability tests were in the valid category. Classical mastery of learning reaches $90.62 \%$ which has met the completeness criteria, namely $\geq 85 \%$ of students have reached the KKM. The increase in students' mathematical reasoning abilities using teaching materials based on a realistic mathematical approach on fraction material seen from $\mathrm{N}$-Gain in the first trial and second trial has increased from 0.36 to 0.50 meaning that it is in the medium category. As well as an increase in the ability of students' mathematical representation using teaching materials based on a realistic mathematical approach on fraction material seen from $\mathrm{N}$ Gain in the first trial and second trial, it increased from 0.43 to 0.50 , meaning that it was in the medium category.
\end{abstract}

Keywords teaching material development; realistic mathematical approach; mathematical reasoning ability; mathematical representation ability

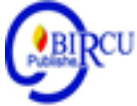

\section{Introduction}

Before the teacher teaches in the classroom, namely as a preparation stage, a teacher is expected to prepare any materials that want to be taught, such as preparing a syllabus, planning for implementing learning, preparing props to be used, preparing questions and directions to lure students to be more active in learning, to understand the situation of students, to understand the weaknesses and strengths of students, and to learn the students' initial knowledge, all of which will be broken down into the teaching materials. Wijaya (2012) in his research shows that the initial ability of teachers in preparing lesson plans is low because teachers are confused in formulating lesson plans because the subjects taught 
are different from their backgrounds and do not have the initiative in compiling lesson plans because they are only copy-paste from MGMP.

From this description, we cannot deny that there are so many teachers who have difficulty in making or compiling teaching materials. as the results of discussions from some fellow teachers in the Subject Teacher Conference (MGMP) forum revealed that: (1) it is very difficult to apply the model or approach to the lesson plans, so that the lesson plans that are made do not reflect the model or approach that attracts students' attention, (2) the lesson plans that made not equipped with LKPD and student books not in accordance with the approach / model they are using, (3) especially in presenting the material there are still some problems in learning experienced by students. Some of these problems include students having difficulty solving problems. Moreover, in solving problems in mathematics, students think that mathematics is a difficult subject to understand. As stated by Sanjaya (2008) "Based on the results of research in Indonesia, it was found that the level of mastery of students in mathematics at all levels of education was still around $34 \%$.

The Indonesian government has made various efforts to improve the quality of teaching and improve student mathematics learning outcomes, because mathematics is a very important science in every level of education pursued by every Indonesian citizen. The government's efforts include developing curricula, providing training to teachers, completing educational infrastructure and even improving teacher welfare. Along with the development of the internet, learning strategies have shifted and various information and communication technology-based learning strategies have emerged, from e-learning models, smart classroom technology, virtual classrooms, belded learning, etc. (Fitri \& Zahari, 2019).

Even though mathematics is one of the most important subjects so that mathematics is studied at all levels of education from elementary to secondary school. The goal of mathematics is given in schools so that students are able to deal with changing circumstances in an ever-developing world, through training to act on the basis of thinking logically, rationally, critically, carefully, honestly and effectively.

To improve mathematics learning outcomes, mathematical reasoning skills are needed. Reasoning is needed to solve existing problems and is needed to make a decision. As stated by US President Thomas Jefferson (2012) as follows: "In a republican nation, whose citizens are to be led by reason and persuasion and not by force, the art of reasoning becomes of first imfortance". This statement shows the importance of reasoning and argumentation that is studied and developed in a country so that every citizen can be led by reason (brain) and not by strength (muscle) alone.

NCTM (2000) states that recognize reasoning and proof as fundamental aspects of mathematics. "People who reason and think analytically tend to note patterns, structure, or regularities in both real-world situations and symbolic objects; they ask if those patterns are accidental or if they occur for a reason; and they conjecture and prove ". This statement explains that reasoning is a fundamental aspect of mathematics. "How a person can reason and think and analyze to get patterns, structures, or rules between real world situations and symbols of objects; they ask if the pattern happened by chance or came about by reason; constructing and building.

Another ability that is needed is the ability of mathematical representation. Because representation is an expression of a mathematical idea displayed by students as a form that represents a problem situation in order to find a solution to the problem. This is in accordance with the opinion of Alhadad \& Syarifah (2010) which states that 
representations are expressions of mathematical ideas displayed by students as a model or substitute form of a problem situation that is used to find a solution to a problem that is being faced as a result of the interpretation of his thoughts. According to Irhamna (2020) Mathematics is a universal science. Mathematics is also seen as the queen of science. According to Adliani (2020) Each mathematics learning material contains a number of concepts that students must like. According to Rambe (2020) Mathematics as a basic science is one of the subjects that play an important role in every level of education as a means of logical, critical, analytical, rational and systematic thinking.

The indicators who show the ability of mathematical representation (Mudzakir, 2006) are:

1. Representing data or information from a representation to a diagram, graph, or table representation.

2. Create equations or mathematical models from other representations given.

3. Make a representation into a diagram, graph, or table representation to clarify the problem and facilitate its resolution.

Various representations need to be raised in every lesson to enrich the student experience. Various mathematical representation skills can be trained to students through the presentation of material or problems that are packaged contextually. This aims to encourage students to reuse or link their problems with previously acquired knowledge.

Students can develop and deepen their understanding of mathematical concepts and relationships as they create, compare and use multiple representations. Representations are useful in all areas of mathematics because they help develop, share and enhance mathematical thinking. (NCTM, 2000).

One other thing that needs to be considered is the learning model. The learning model should be selected and designed in such a way that it emphasizes student activities, so that it is necessary to design a teaching that provides the widest possible opportunity for students to learn by building their own knowledge. With this learning, it is expected that better learning achievement can be obtained.

One of the mathematics learning models is a realistic material approach or commonly known as Realistic Mathematics Education (RME). This approach is one of the appropriate learning alternatives because with this learning model students are required to construct knowledge on their own by means of activities carried out in learning activities. The main idea of learning using the RME learning model is that students should be given the opportunity to reinvent mathematical concepts with adult guidance. The principle of rediscovering means that students are given the opportunity to discover their own mathematical concepts by solving various contextual problems given at the beginning of the lesson. Based on the problems, students build a model of the problem situation and then compile a mathematical model to (model for) solve until they gain formal mathematical knowledge (Gravemeijer, 1994). Apart from that in this view, mathematics is seen as a human activity. Therefore mathematics learning must be linked to reality and mathematics as part of human activities. Therefore mathematics learning must be linked to reality and mathematics as part of human activities.

The RME learning model has been developed in the Netherlands for approximately 30 years showing good results. RME has also been developed in several other countries such as the USA (which is known as Mathematics in Context), South Africa, Malaysia, England, Brazil, and others (Fauzan, 2001). The report from TIMSS (Third International Mathematics and Science Study) states that based on the TIMSS assessment, students in the Netherlands get satisfactory results in both computational skills and problem-solving abilities (in Yuwono, 2001). 
Based on the description above, the researcher is interested in conducting a research entitled "Development of Mathematics Teaching Materials Based on a Realistic Mathematical Approach (PMR) to Improve the Mathematical Reasoning Ability and Representation of Class VII Students of SMP Muhammadiyah 47 Medan Sunggal".

\section{Research Methods}

The subjects in this study were seventh grade students of SMP Muhammadiyah 47 Medan Sunggal for the 2020/2021 academic year. While the object in this study is the developed mathematics learning tool. The learning tool developed in this study is the Fractional Number Operation material. The trial design that will be used in the development of the instrument is the One - group pretest - posttest design. As follows :

\begin{tabular}{|ccc|}
\hline Test & Treatment & Test \\
$\mathrm{T}_{1}$ & $\mathrm{x}$ & $\mathrm{T}_{2}$ \\
\hline
\end{tabular}

Information :

$\mathrm{T}_{1}=$ Pretest

$\mathrm{T}_{2}=$ Posttest

$\mathrm{X}=$ Realistic mathematics learning treatment

This research is categorized into the types of development research (development research). This study uses the 4-D development model Thiagarajan, Semmel and Semmel (1974) by developing teaching materials with a realistic mathematical approach.

The development model was chosen because of the consideration of the development steps in the detailed 4-D development model but it was simple and easy to follow the development procedure. This development model is programmed with a systematic sequence of activities to solve learning problems tailored to the needs of students. The advantage of the 4-D development model is that it is the basis for developing learning tools because the implementation stages are divided in detail and systematically.

Thus, the product of this research is a valid, practical and effective problem-based teaching material. The development of teaching materials is in the form of a Learning Implementation Plan (RPP), Student Book (BS), Student Worksheets (LKPD) and research instruments in the form of a Mathematical Reasoning Ability Test (TKPM) and a Mathematical Representation Ability Test (TKRM).

\section{Discussion}

The results of data analysis obtained from the results of trials I and II show: (1) the teaching materials based on the developed realistic mathematics approach are valid; (2) realistic mathematics approach model teaching materials that are developed practically; (3) teaching materials based on a realistic mathematical approach that is developed to be developed effectively; (4) there is an increase in students' mathematical reasoning abilities by using teaching materials based on the developed realistic mathematics approach; (5) there is an increase in students' mathematical representation abilities using teaching materials based on the developed realistic mathematics approach;

Based on the results of the validation of teaching materials based on the realistic mathematical approach developed, it was found that teaching materials based on the realistic mathematics approach, namely the Learning Implementation Plan (RPP), Student Book (BS) and Student Worksheet (LKPD) were declared valid or had a good degree of 
validity. Furthermore, the validation results of the students 'mathematical reasoning ability tests are also valid or have a good degree of validity and the validation results of the students' mathematical representation ability tests are also valid.This shows that teaching materials based on a realistic mathematical approach are developed both RPP, BS, LKPD, reasoning ability tests students 'mathematics and the test of students' mathematical representation ability have met the validity criteria.

The device developed is said to meet valid indicators if the teaching materials based on a realistic mathematical approach are at least in the assessment category $(4 \leq \mathrm{Va}<5)$. The results of giving the device validation sheet to the validator regarding the response of the developed device can be seen in Table 1 below:

Table 1. Validator's Assessment of the Tools Developed

\begin{tabular}{|l|l|c|c|}
\hline No. & \multicolumn{1}{|c|}{ The Object Being Rated } & $\begin{array}{c}\text { The Average Value } \\
\text { Of The Total Validity }\end{array}$ & $\begin{array}{c}\text { Validation } \\
\text { Level }\end{array}$ \\
\hline 1. & Lesson Plan (RPP) & 4,81 & Valid \\
\hline 2. & Student Book (BS) & 4,83 & Valid \\
\hline 3. & Student Worksheets (LKPD) & 4,85 & Valid \\
\hline
\end{tabular}

Based on the validity criteria, it can be said that the teaching materials developed are valid. This is in accordance with the results of Dahlia and Hasibuan's research that the teaching materials based on the realistic mathematical approach developed meet valid criteria. Valid is illustrated by the results of the validator's assessment that all validators state both based on content (according to the curriculum), construct (according to the characteristics / learning principles) and language (according to the prevailing language rules, namely enhanced spelling).

In this study, the teaching materials developed are said to be practical if they meet the following criteria: (1) expert and practitioner judgment that the tool can be used with little or no revision; (2) the teacher states that the tools developed are easy to use; (3) students stated that the devices developed were easy to use and (3) the results of observations of the implementation of teaching materials in the class were in the good or very good category.

The results of the assessment of the practicality of teaching materials were obtained from expert / practitioner assessments which stated that the developed teaching materials could be used with little or no revision. Based on the results of expert assessments, the components of teaching materials developed in the form of a Learning Implementation Plan (RPP), Student Book (BS), Student Worksheet (LKPD), tests of students' mathematical problem solving abilities are practical / can be used with minor revisions.

For practical assessment, then it is reviewed from the teacher and students who state that the teaching materials developed are easy to use. Then, the criteria for practicality in terms of the implementation of the teaching materials in this study have also met the practical criteria. In the first trial and II test, the implementation of teaching materials has met the specified criteria, which has reached the good category $(80 \leq \mathrm{k}<90)$. This is supported by the results of Eka's (2015) research which shows that the development of teaching materials with a realistic mathematical approach-based approach that is developed meets practical criteria.

Based on the description above, it can be concluded that the teaching materials developed based on the realistic mathematical approach have fulfilled the practicality as expected. Thus teaching materials based on a realistic mathematical approach that are developed are easy and can be implemented by teachers and students. 
Based on the results of trial I and trial II, the teaching materials based on the realistic mathematical approach developed have met the effective category in terms of: (1) classical student learning completeness; (2) achievement of learning objectives; (3) learning time and (4) student response. The following will present a discussion for each indicator in measuring and seeing the effectiveness of teaching materials based on a realistic mathematics approach.

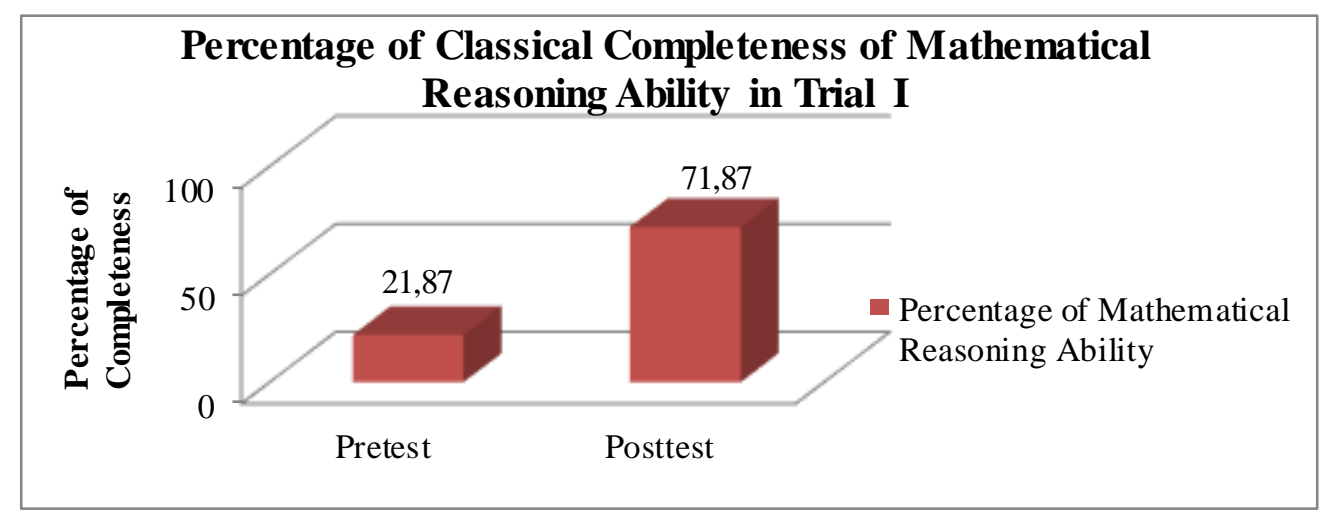

Figure 1. Percentage of Classical Completeness of Students' Mathematical Reasoning Ability in Trial I

Based on the results of the posttest analysis stated earlier that in the first trial the percentage of classical completeness of mathematical reasoning ability was $71.87 \%$ while in the second trial the percentage of completeness classified as mathematical problem solving ability was $90.62 \%$. When viewed from the results of classical student learning completeness students' mathematical problem solving abilities, the mastery obtained from the results of trial I did not meet the classical completeness criteria while in the second trial it had met the classical completeness criteria.

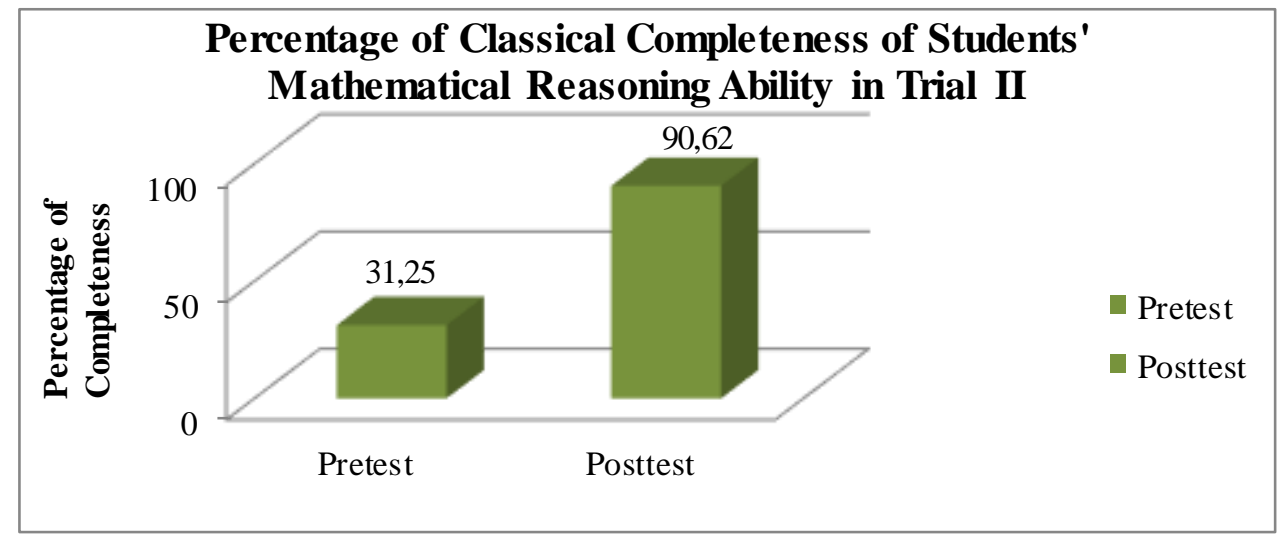

Figure 2. Percentage of Classical Completeness of Students' Mathematical Reasoning Ability in Trial II

Based on the data in Table 1 and Figure 2, it can be seen that the classical completeness of the results of students' mathematical reasoning abilities in the pretest trial II was $31.25 \%$ and the posttest trial II was $90.62 \%$. In accordance with the completeness criteria of classical student learning outcomes, namely at least $85 \%$ of students who took the mathematical reasoning ability test were able to achieve a score of $\geq 75$. Thus, the posttest results of students' mathematical reasoning abilities had fulfilled classical 
completeness because they obtained a percentage of completeness of $90.62 \%$. So it can be concluded that in Trial II the application of teaching materials based on the realistic mathematical approach developed has met the classical achievement criteria.

Furthermore, based on the results of the posttest analysis stated earlier that in the first trial the percentage of classical completeness of the mathematical representation ability was $78.12 \%$ while in the second trial the percentage of completeness classified as the mathematical problem solving ability was $90.62 \%$. When viewed from the results of classical student learning completeness students' mathematical problem solving abilities, the mastery obtained from the results of trial I did not meet the classical completeness criteria while in the second trial it had met the classical completeness criteria.

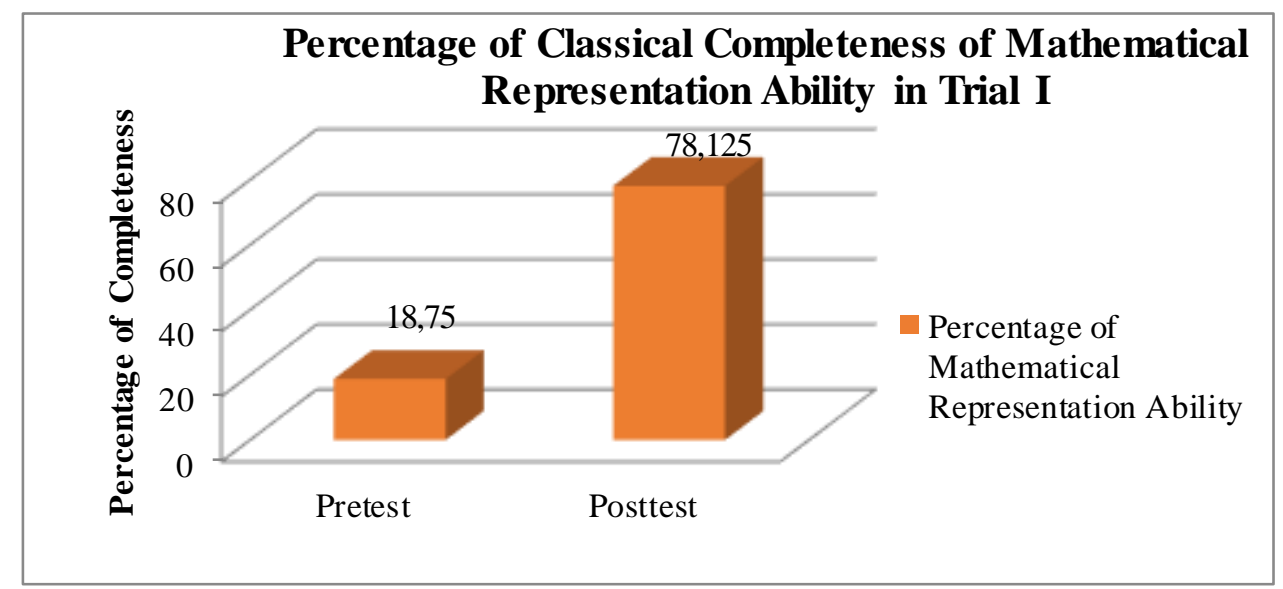

Figure 3. Percentage of Classical Completeness of Students' Mathematical Reasoning Ability in Trial I

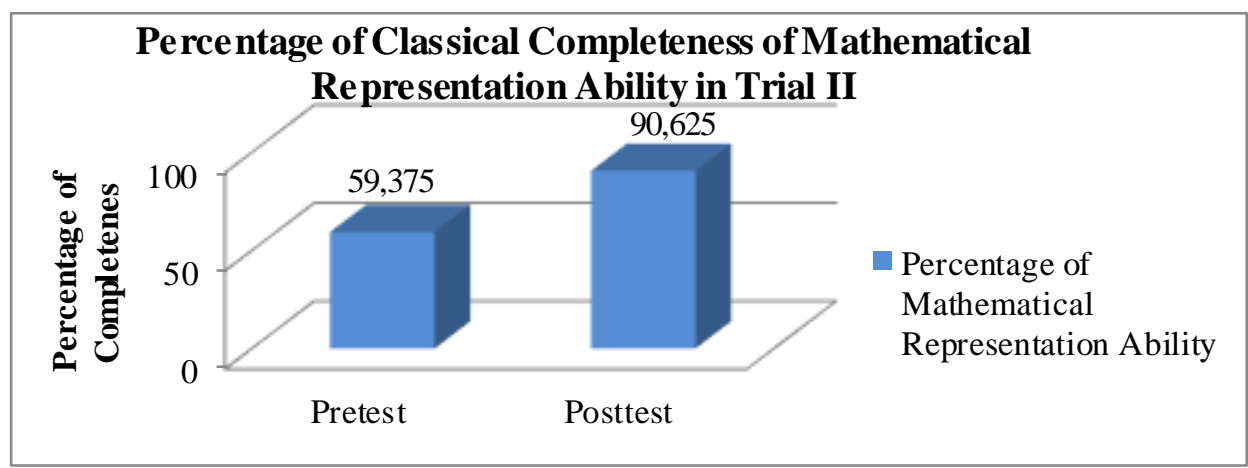

Figure 4. Percentage of Classical Completeness of Students' Mathematical Reasoning Ability in Trial II

Based on the data in Figure 4, it can be seen that the classical completeness of the results of the students' mathematical representation ability in the pretest trial II was $59.375 \%$, while in the posttest trial II it was $90.625 \%$. In accordance with the completeness criteria of classical student learning outcomes, namely at least $85 \%$ of students who take the Mathematical Representation Ability test are able to achieve a score of $\geq 75$. Thus, the posttest results of the students' mathematical representation ability have met completeness classically, namely obtaining a completeness percentage of $90.625 \%$. So it can be concluded that in Trial II the application of teaching materials based on the realistic mathematical approach developed has met the classical achievement criteria. 
Based on the results of the data analysis of the results of trial I and trial II, it was found that the average percentage of student responses in each trial was positive.

the average results of the percentage of students' positive responses to each aspect of the student's response were as follows: (1) students who expressed pleasure in the teaching material components were $95.58 \%$; (2) students stated that the components of teaching materials and learning activities were still new as much as 96.22\%; (3) students who expressed interest in learning mathematics in other materials such as learning conducted were 96.8\%; (4) students who stated that the language in the student books, LKPD and tests was clear was 92.16\%; (5) students who expressed interest in the appearance of student books and LKPD were 95.25\%; and (6) students who stated that learning based on a realistic mathematics approach was attractive, made fun, useful and helpful, and made them motivated in learning mathematics as much as $90.62 \%$. The average percentage of students' total positive responses in Trial II was $94.16 \%$. If the results of this analysis are referred to the criteria set out in chapter III, it can be concluded that the student response to the components and learning activities is very positive. Because, more than $80 \%$ of students gave positive responses to the components of the teaching materials developed.

Thus, it is known that the results of trial II are better than trial I. This is because the teaching materials based on the realistic mathematical approach used in the second trial are teaching materials based on the realistic mathematical approach results from the revised trial I, so based on the test results Trial II can be concluded that the teaching materials based on realistic mathematical approaches have met the quality of practical and effective teaching materials.

This means that students give a positive response to the components of teaching materials based on the developed realistic mathematics approach. Student responses given in each trial have reached the predetermined criteria category, namely $\geq 80 \%$. This shows that the teaching materials through the developed realistic mathematics approach have met the criteria of being effective in terms of student responses.

Based on the explanation of the research results and supporting research, it can be concluded that the components of teaching materials based on the realistic mathematics approach developed have a positive contribution to student responses in learning.

Based on the results of the analysis of the increase in students' mathematical reasoning abilities in the first trial and the second trial, it showed that the average mathematical problem solving ability of students in the pretest test I results was 64.59 and increased in the posttest trial I to 74.19. Then in the second trial, the average result of students' mathematical reasoning ability at the pretest trial II was 66.25 and it increased again in the posttest trial II of 82.66. Thus, there was an increase in the average score of students' mathematical reasoning abilities by 9.6 in the first trial and an increase of 16.41 in the second trial. Meanwhile, the increase in the results of the posttest trial I and trial II was 8.47 .

In this study, the level of student mastery in terms of mathematical reasoning abilities using a mathematical reasoning ability test that has been developed. The description of the results of the students' mathematical reasoning abilities in the first trial is shown in Table 2. below.

Table 2. Descriptions of Students' Mathematical Reasoning Ability Results in Trial I.

\begin{tabular}{|c|c|c|}
\hline Information & $\begin{array}{c}\text { Mathematical Reasoning } \\
\text { Ability Pretest }\end{array}$ & $\begin{array}{c}\text { Posttest of Mathematical } \\
\text { Reas oning Ability }\end{array}$ \\
\hline The Highest Score & 87,5 & 93,75 \\
\hline Lowest Value & 46,875 & 62,5 \\
\hline Average & 64,60 & 77,39 \\
\hline
\end{tabular}


Based on Table 2, it shows that the average mathematical reasoning ability of students on the pretest results is 64.6 and posttests is 77.4. The description of the results of students' mathematical reasoning abilities in the second trial is shown in Table 3 below.

Table 3. Description of the Results of Students' Mathematical Reasoning Ability Trial II

\begin{tabular}{|c|c|c|}
\hline Information & $\begin{array}{c}\text { Mathematical Reasoning } \\
\text { Ability Pretest }\end{array}$ & $\begin{array}{c}\text { Posttest of Mathematical } \\
\text { Reas oning Ability }\end{array}$ \\
\hline The Highest Score & 84,3 & 95,3 \\
\hline Lowest Value & 50 & 70,3 \\
\hline Average & 66,25 & 82,6 \\
\hline
\end{tabular}

Based on Table 3, it shows that the average mathematical reasoning ability of students on the pretest results is 66.25 and the posttests are 82.6. A summary of the N-Gain results based on the improvement categories that have been defined in Table 4 below.

Table 4. Summary of N-Gain Results of Students' Mathematical Problem Solving Ability Trial I

\begin{tabular}{|c|c|c|c|}
\hline Range & Category Improvement & The Number Of Students & Percentage \\
\hline $\mathrm{N} \geq 0,7$ & High & 4 & $12,5 \%$ \\
\hline $0,3 \leq \mathrm{N}<0,7$ & Medium & 22 & $68,75 \%$ \\
\hline $\mathrm{N}<0,3$ & Low & 6 & $18,75 \%$ \\
\hline
\end{tabular}

Based on Table 4 above, it can be seen that only 4 students got $\mathrm{N}$-Gain scores in the range> 0.7. For students who experienced an increase in students' mathematical reasoning abilities with the "Medium" category or got an N-Gain score of $0.3<\mathrm{g} \leq 0.7$, there were 22 people and 6 people who got an $\mathrm{N}$-Gain score $\mathrm{g} \leq 0.3$ with the "Low" category. ". The average gain in the first trial was 036, which is in the medium category. So, it can be concluded that there is an increase in students' mathematical reasoning abilities after implementing learning using teaching materials based on a realistic mathematical approach in trial $\mathrm{I}$.

Table 5. Summary of N-Gain Results in the Mathematical Reasoning Ability Test in Trial

\begin{tabular}{|c|c|c|c|}
\hline \multicolumn{5}{|c|}{ II } \\
\hline $\mathrm{N} \geq 0,7$ & Category Improvement & The Number Of Students & Percentage \\
\hline $0,3 \leq \mathrm{N}<0,7$ & High & 5 & $15,625 \%$ \\
\hline $\mathrm{N}<0,3$ & Medium & 27 & $84,375 \%$ \\
\hline
\end{tabular}

Based on Table 5, if it is seen based on the N-Gain calculation to see the increase in students' mathematical reasoning abilities in the first trial and the second trial, it has increased from 0.36 to 0.50 , meaning that it is in the "medium" category. This shows that students' mathematical reasoning abilities using teaching materials developed based on a realistic mathematics approach have increased from trial I to trial II. Thus the use of teaching materials based on the developed realistic mathematical approach can improve students' mathematical reasoning abilities in the second trial.

Based on the results of the analysis of the increase in the ability of students 'mathematical representation in the first trial and the second trial, it showed that the average ability of students' mathematical representation in the pretest test I was 64.72 and 
increased in the posttest test I to 79.68. Then in the second trial, the average result of the students' mathematical representation ability at the pretest trial II was 73.07 and it increased again in the posttest trial II of 85.66. Thus, there was an increase in the average score of students' mathematical representation abilities by 14.96 in the first trial and an increase of 12.59 in the second trial. Meanwhile, the increase in the results of the posttest trial I and trial II was 5.98 .

Furthermore, in this study, the level of mastery of students is also seen from the mathematical representation ability using the mathematical representation ability test that has been developed.

Table 6. Descriptions of Students' Mathematical Representation Ability Results in Trial I

\begin{tabular}{|c|c|c|}
\hline Information & $\begin{array}{c}\text { Mathematical Representation } \\
\text { Ability Pretest }\end{array}$ & $\begin{array}{c}\text { Posttest of Mathematical } \\
\text { Representation Ability }\end{array}$ \\
\hline The Highest Score & 83,33 & 91,66 \\
\hline Lowest Value & 47,22 & 61,11 \\
\hline Average & 64,72 & 79,68 \\
\hline
\end{tabular}

Based on Table 6, it shows that the average mathematical representation ability of students on the pretests results is 64.72 and posttests is 79.68. Furthermore, in this study, the level of mastery of students is also seen from the mathematical representation ability using the mathematical representation ability test that has been developed.

Table 7. Descriptions of Students' Mathematical Representation Ability Results in Trial II

\begin{tabular}{|c|c|c|}
\hline Information & $\begin{array}{c}\text { Mathematical Representation } \\
\text { Ability Pretest }\end{array}$ & $\begin{array}{c}\text { Posttest of Mathematical } \\
\text { Representation Ability }\end{array}$ \\
\hline The Highest Score & 83,33 & 94,44 \\
\hline Lowest Value & 58,33 & 72,22 \\
\hline Average & 73,07 & 85,66 \\
\hline
\end{tabular}

Based on Table 7, it shows that the average mathematical representation ability of students on the pretests results is 73.01 and posttests is 85.66.

Table 8. Summary of N-Gain Results of Students' Mathematical Representation Ability Trial I

\begin{tabular}{|c|c|c|c|}
\hline Range & Category Improvement & The Number Of Students & Percentage \\
\hline $\mathrm{N} \geq 0,7$ & High & 2 & $6,25 \%$ \\
\hline $0,3 \leq \mathrm{N}<0,7$ & Medium & 26 & $81,25 \%$ \\
\hline $\mathrm{N}<0,3$ & Low & 4 & $12,5 \%$ \\
\hline
\end{tabular}

Based on Table 8 above, it can be seen that only 2 students got an N-Gain score in the range> 0.7. For students who experienced an increase in the mathematical representation ability of students with the "moderate" category or got an N-Gain score of $0.3<\mathrm{g} \leq 0.7$, there were 26 people and 4 people who got an $\mathrm{N}$-Gain score $\mathrm{g} \leq 0.3$ with the "Low" category. ". The average gain in the first trial was 0.43 , which is in the medium category. So, it can be concluded that there is an increase in students' mathematical reasoning abilities after implementing learning using teaching materials based on a realistic mathematical approach in trial I. 
Table 9. Summary of N-Gain Results of Students' Mathematical Representation Ability in Trial II

\begin{tabular}{|c|c|c|c|}
\hline Range & Category Improvement & The Number Of Students & Percentage \\
\hline $\mathrm{N} \geq 0,7$ & High & 3 & $9,375 \%$ \\
\hline $0,3 \leq \mathrm{N}<0,7$ & Medium & 27 & $84,375 \%$ \\
\hline $\mathrm{N}<0,3$ & Low & 2 & $6,25 \%$ \\
\hline
\end{tabular}

Based on Table 9 above, it can be seen that there were 3 students who got N-Gain scores in the range> 0.7. For students who experienced an increase in the mathematical representation ability of students with the "moderate" category or got an N-Gain score of $0.3<\mathrm{g} \leq 0.7$, there were 27 people and 2 people who got an $\mathrm{N}$-Gain score $\mathrm{g} \leq 0.3$ with the "Low" category. ". The average gain in the first trial was 0.50 , namely in the medium category. So, it can be concluded that there is an increase in students' mathematical reasoning abilities after implementing learning using teaching materials based on a realistic mathematics approach in the second trial.

Based on Table 9, if it is seen based on the N-Gain calculation to see the increase in the ability of students' mathematical representation in the first trial and the second trial, it has increased from 0.43 to 0.50 , meaning that it is in the "medium" category. This shows that students' mathematical reasoning abilities using teaching materials developed based on a realistic mathematics approach have increased from trial I to trial II. Thus the use of teaching materials based on the developed realistic mathematics approach can improve students' mathematical representation abilities in the second trial.

Then if it is seen based on the calculation of N-Gain to see the increase in the ability of students' mathematical representation in the first trial and second trial, it has increased from 0.43 to 0.50 , meaning that it is in the "medium" category. This shows the ability of students' mathematical representation using teaching materials developed based on a realistic mathematical approach has increased from trial I to trial II.

\section{Conclusion}

The Based on the results of data analysis and discussion in this study, the following conclusions are stated:

1. Teaching materials based on the realistic mathematics approach meet the valid criteria with an average value of the total validity of the RPP of 4.81, student books of 4.83 and LKPD of 4.85, tests of students' mathematical reasoning abilities and tests of mathematical representation abilities have been at valid category.

2. Teaching materials based on realistic mathematical approaches in improving students' mathematical reasoning abilities and mathematical representations have been effectively used in learning, which includes: (1) completeness of classical learning reaches $90.62 \%$ which has met the completeness criteria, namely $\geq 85 \%$ of students have achieved KKM; (2) the teacher's ability to manage learning is in a good category; and (3) the student's response to the components of learning tools and learning activities is positive.

3. Increasing students 'mathematical reasoning abilities using teaching materials based on realistic mathematical approaches on fraction material seen from the average students' mathematical reasoning abilities in the pretest I test results of 64.59 and increased in the posttest I trial to 74.19. Then in the second trial, the average result of students' mathematical reasoning ability at the pretest trial II was 66.25 and it increased again in 
the posttest trial II of 82.66. Furthermore, seen from the N-Gain in trial I and trial II it has increased from 0.36 to 0.50 meaning that it is in the medium category.

4. Increasing the ability of students 'mathematical representation using teaching materials based on a realistic mathematical approach to fraction material seen from the average ability of students' mathematical representation in the pretest results of the first trial of 64.72 and increased in the posttest first trial to 79.68. Then in the second trial, the average result of the students' mathematical reasoning ability in the pretest trial II was 73.07 and again increased in the posttest trial II of 85.66. Furthermore, seen from the $\mathrm{N}$ Gain in trial I and trial II, it has increased from 0.43 to 0.50 which means that it is in the medium category.

\section{References}

Adliani, S., et al. (2020). The Influence of Realistic Mathematical Approach to Understanding Concept and the Mathematical Connection Ability of Islamic Private Vocational School Students Hikmatul Fadhillah Medan Class VII. Budapest International Research and Critics in Linguistics and Education (BirLE) Journal, 487-499.

Akker, J, V, D. (1999). Principles and Methods of Development Research. Dalam Plomp, T; Nieveen, N; Gustafson, K; Branch, R.M; dan Van Den Akker, J (eds). Design Approaches and Tools in Education and Training. London: Kluwer Academic Publisher.

Alhadad, Fadillah Syarifah. (2010). Meningkatkan Kemampuan Representasi Multipel Matematis, Pemecahan Masalah Matematis dan Self Esteem Siswa SMP Melalui Pembelajaran Open Ended. Disertasi. Bandung : UPI

Amin. A.K. (2017). Implementasi Pembelajaran Matematika Realistik Dengan Model Kooperatif Pada Materi Persamaan Linear Satu Variabel di MTs Darul Ulum Kelas VII. (Online). Artikel https://www.researchgate.net/publication/320237765.

Depdiknas. (2004). Peraturan Dirjen Dikdasmen No.506/c/PP/2004 tanggal 11 November 2004 tentang Penilaian Perkembangan Anak Didik Sekolah Menengah Pertama $(S M P)$. Jakarta : Dirjen Dikdasmen Depdiknas.

Eka, K. (2015). Pengembangan Majalah Biosmart Invertebrata untuk Meningkatkan Aktivitas dan Hasil Belajar Siswa SMA. (Jurnal Online) http://lib.unnes.ac.id/23423/1/SKRIPSI-EkaKurniawati-4401411009.pdf

Fauzan, (2001). (prinsip dan karakterikstik pendekatan matematika realistik), [online] diakses dari karakteristik-pendekatan.html. [diakses pada tanggal 27 Februari 2017]

Fauzi, K.A., dan Fikri Mukasyaf Lintasan Belajar Kemampuan Pemecahan Masalah Siswa Berbasis Pendekatan Metakognisi Topik Gsl Di SMP Imelda Medan. Jurnal Penelitian Bidang Pendidikan 24(1), p. 7-14.

Fitri, S., \& Zahari, C.L. (2019). The implementation of blended learning to improve understanding of mathematics. The Sixth Seminar Nasional Pendidikan Matematika Universitas Ahmad Dahlan 2018: IOP Conf. Series: Journal of Physics: Conf. Series 1188 (2019) 012109, 2018, doi:10.1088/1742-6596/1188/1/012109.

Gravemeijer. (1994). Developing Realistic Mathematics Education. Utrecht: Freudenthal Institute. http://repository.upi.edu/operator/upload/d_mat-0604957_chapter2.pdf

Hutagaol, K. (2013). Pembelajaran Kontekstual untuk Meningkatkan Representasi Matematis Siswa Sekolah Menengah Pertama. Jurnal Ilmiah Program Studi Matematika STKIP Siliwangi Bandung, 2 (1). p.85-99. 
Irhamna, et al. (2020). Contribution of Mathematical Anxiety, Learning Motivation and Self-Confidence to Student's Mathematical Problem Solving. Budapest International Research and Critics in Linguistics and Education (BirLE) Journal, 1759-1772.

Jefferson, Thomas. (2012). HUMA 1710 The Art of Thinking : In The Hongkong Content.

Mudzakir, H. S. (2006). Strategi Pembelajaran Think-Talk-Write untuk Meningkatkan Kemampuan Representasi Matematik Beragam Siswa SMP. Disertasi UPI [Online].

NCTM. (2000). Principles and Standards for School Mathematics Drive, Reston, VA: The NCTM.

Nieveen, N. (2007). An Introduction to Education Design Research. China.

Rambe, N., et al. (2020). The Effect of the Jigsaw Cooperative Learning Model and the Student's Initial Mathematical Abilities and Its Effect on the Mathematical Representation Ability and Learning Motivation of Students in the PAB 10 Sampali Private Elementary School. Budapest International Research and Critics in Linguistics and Education (BirLE) Journal, 1591-1599.

Sanjaya, W. (2008). Strategi Pembelajaran Berorientasi Standar Proses Pendidikan. Jakarta: KencanaPrenada Media.

Thiagarajan, S. Semmel, D.S. Semmel, M. (1974). Instructional Development for Training Teachers of Expectional Children.A Sourse Book.Blomington: Central for Innovation on Teaching The Handicapped.

Wijaya, A. (2012). Pendidikan Matematika Realistik. Yogyakarta: Graha Ilmu.

Yuwono, Teguh. (2001). Manajemen Otonomi Daerah : Membangun Daerah Berdasarkan Paradigma Baru. Semarang: Ciyapps Diponegoro Universiti. 